\title{
Cataracts and Hernias: Aspects of Surgical Practice in the Fourteenth Century
}

\author{
MICHAEL McVAUGH*
}

Let me begin by paraphrasing a daughter's letter to her father, of June 1326:

I haven't wanted to upset you, but I am suffering from an illness of the head that will totally deprive me of sight, though I may be able to tell light from dark. Can you please find someone there who can help me better than the doctors here? They are calling this illness "cataract", and apparently it can be cured if mine is the right kind, though no one here says it is. ${ }^{1}$

The frightened daughter is the 25-year-old Princess Isabel, wife of Frederick of Austria, writing from Graz to her father James II of Aragon. Her anxious father wrote back immediately, asking her what her doctors said her symptoms were and what they thought had caused the illness, so that he could summon his own medical experts to see if they knew how she could be treated. Unfortunately, as it happened, James himself died the next year, before he could do anything further. ${ }^{2}$

I hope that readers find the uncertainty in this exchange at least a little surprising. Was cataract such an unfamiliar diagnosis in the early fourteenth century? Was it

* Prof. Michael McVaugh, Department of History, CB 3195, University of North Carolina, Chapel Hill, NC 27599-3195, USA.

This is a revised version of the 1997 Amalie and Edward Kass Lecture, given at the Wellcome Institute for the History of Medicine on 14 May 1997. I am deeply grateful to Laurence $M$ Eldredge and to Klaus-Dietrich Fischer, and to two anonymous referees, for their very helpful criticisms and corrections.

\footnotetext{
1 "Nam cum per mancipacionem domini conthoralis nostri, de qua tamen feliciter est ereptus, nova nisi que Paternitatis Vestre perturbassent precordia, tum etiam post liberacionem huiusmodi gravissimam egritudinem, in quam incidimus continuo, de qua in omni parte corporis nostri heu nondum convaluimus, nequivimus nunciare. Infirmitas namque predicta nostri capitis nimis gravis visu, oculos tamen pulcherrimos nobis habentibus totaliter nos privabit, nisi in quantum lucem a tenebris et splendorem solis, cum inspicimus, nos gravantem considerare possumus seu valemus. Quapropter Vestram Caritatem obnixius deprecamur,
}

quatenus de aliquo magistro experto, qui in partibus vestris subtiliores et prudenciores nostris magistris poterunt reperiri, nobis curetis providere quantocius, sicut nostram gloriam et quod pluris est diligitis sospitatem. Et ut plenius cognoscatis negocium, est quedam infirmitas oculorum, quam vocant medici cateractam, de qua a pluribus curate fuissemus, si nostra fuissent huiusmodi, quoniam nullatenus esse asserunt nec affirmant": Isabel's letter to her father announcing her illness (4 June 1326; CRD Jaume II 8791) is published in Heinrich Finke, Acta Aragonensia, 3 vols, Berlin, 1908-22 (rpt. Aalen, 1966 ), vol. 1, pp. 379-80, and in Heinrich $F$ von Zeissberg, 'Register Nr. 318 des Archives der aragonesischen Krone in Barcelona', Sitzungsberichte der philosophisch-historischen Classe der kaiserlichen Akademie der Wissenschaften, 1899, 140, part 1: pp. 89-90. I have emended the text slightly after studying the original. On the course of the blindness, see the references cited by Zeissberg on p. 88 .

${ }^{2}$ Michael R McVaugh, Medicine before the plague: practitioners and their patients in the Crown of Aragon, 1285-1345, Cambridge University Press, 1993, p. 26. 


\section{Michael McVaugh}

so unclear how it might be treated, and by whom? These are some of the questions I mean to address here, but solving them will lead to others about the history of medieval surgery more broadly-and will suggest, I hope, that its development was not quite as straightforward as its traditional history would imply.

That history describes a simple story of progress in stages: of how in about 1170 Roger Frugardi composed his Chirurgia, the first medieval treatise of operative surgery; of how Roger's surgery was then glossed in the next century by other practitioners, Roland of Parma and the Four Masters, who helped elevate surgery from a manual craft to a discipline with a literary tradition of its own that imitated the new professionalizing academic medicine and hoped to share in its growing prestige; of how this tradition of surgical literature grew in the later thirteenth century, with Bruno and Theodoric further imitating medicine in incorporating material from the recent Greco-Arabic scientific translations, and with the insistence, beginning with William of Saliceto about 1270, that a thorough understanding of anatomy was essential for sound surgical practice; and finally, of how this Italian surgical tradition came to France in the 1290s with Lanfranc of Milan and was developed at Montpellier and Paris by Henri de Mondeville early in the fourteenth century and by Guy de Chauliac in the $1360 \mathrm{~s}^{3}$ These authors were increasingly conscious of belonging to a coherent tradition, so that it was actually Guy de Chauliac who originated the canonical history of progress that I have just summarized. And not only that, they grew more and more insistent that their literacy, their scientific sophistication, their possession of anatomical knowledge were things that set them apart from mere empirics while making them more comparable to learned physicians.

This canonical history has always fitted neatly into triumphalist stories of the continuing advance of medicine, and it might be thought ripe for deconstruction. Here, however, I simply want to suggest that this picture of an increasingly sophisticated, literate surgical tradition in the Middle Ages ought to be put into a context of occupational differentiation. We automatically refer to these writers of the late thirteenth century as surgeons, but it is more illuminating to think of them as practitioners who were in the process of becoming surgeons, struggling to create a niche for themselves as a group in the world of competitive health care-between physicians, on the one hand, who were acquiring professional status through their university training and certain other non-academic practitioners, on the other, whom the surgeons-to-be tried to rise above by labelling them "empirics", but who would not always have been easy to distinguish from the new "surgeons" on the grounds of their ability or intelligence or technical skill.

From this perspective, the deliberate emphasis these writers gave to the anatomical foundations of their subject, after the 1270s, is significant because it narrowed the kind of health care that such surgeons would thereafter be able to give. In choosing to take this direction, in insisting on anatomical knowledge as the basis for their

\footnotetext{
${ }^{3}$ A thoughtful presentation of this traditional history is set out in $\mathrm{C} \mathrm{H}$ Talbot, Medicine in
}

medieval England, London, Oldbourne, 1967, pp. 88-104. 


\section{Aspects of Surgical Practice in the Fourteenth Century}

practice, they were unknowingly committing themselves to a particular conceptualization of illness. Owsei Temkin once contrasted two opposing ways of understanding diseases, as specific entities or as sicknesses in individual patients, and proposed that this opposition is part of what marks off the surgeon from the physician: surgeons think in terms of a localized, anatomy-based pathology, while physicians tend to adopt an individualized, physiological one. ${ }^{4}$ At the risk of paradox, I want to suggest that by choosing to emphasize anatomy these practitioners were in effect finally deciding to become surgeons - fully a century after Roger Frugardi had composed his Chirurgia.

Temkin went on to point out that these different perceptions of how illness is to be understood have consequences for how it is to be treated, and if we apply this insight to the anatomy-based practitioners of the late thirteenth century and thereafter, now recognizably surgeons, and focus on the kinds of treatment they were now expected to offer to their society, we can begin to appreciate that they had created certain occupational difficulties for themselves by emphasizing anatomy. We can see something of these difficulties if we look closely at two health problems that were urgent enough to arouse significant pressure for treatment, and see how surgeons (and physicians) dealt with them. These problems are cataracts and hernias.

\section{The Treatment of Hernia: Surgeons and Their "Empiric" Competitors}

At the end of the thirteenth century, the Latin surgical tradition had come to recognize the technical possibility of operating to correct what today would be called indirect inguinal hernia. ${ }^{5}$ This condition arises when the internal inguinal ring in the abdomen "stretches" enough to allow dilation and distention of a vestigial peritoneal sac by intestine or omentum; the resulting hernia may ultimately descend along the spermatic cord, within its surrounding fascia, and into the scrotum. In extreme cases, when the intestine passes through the ring within the peritoneal sac and is caught, the trapped intestine becomes gangrenous and the patient may die. ${ }^{6}$

In describing this condition, medieval surgeons spoke not of the spermatic cord but of the "didymus": they assumed that the spermatic cord was enveloped by a membrane continuous with the abdominal peritoneum, in effect constituting an open

\footnotetext{
${ }^{4}$ Owsei Temkin, 'The scientific approach to disease: specific entity and individual sickness', in A C Crombie (ed.), Scientific change, New York, Basic Books, 1963, pp. 629-47. The point is taken up again in Christopher Lawrence (ed.), Medical theory, surgical practice, London and New York, Routledge, 1992, esp. pp. 16-21.

${ }^{5}$ What follows abbreviates a portion of Michael McVaugh, 'Treatment of hernia in the later Middle Ages: surgical correction and social construction', in Roger French et al. (eds), Medicine from the black death to the French disease, Aldershot, Ashgate, 1998, pp. 131-55. The recent study by Gundolf Keil, 'Les opérations des hernies de Roger Frugardi à Caspar Stromayr', in Carl Deroux (ed.), Maladie
}

et maladies dans les textes latins antiques et médiévaux, Collection Latomus, vol. 242, Brussels, Latomus, 1998, pp. 434 44, suggests that hernia treatment in the thirteenth and fourteenth centuries was perhaps slightly more static than I perceive it to have been.

${ }^{6} \mathrm{My}$ account is based on Lloyd $\mathbf{M}$ Nyhus and Robert E Condon, Hernia, 2nd ed., Philadelphia and Toronto, Lippincott, 1978; and Leo M Zimmerman and Barry $\mathbf{J}$ Anson, Anatomy and surgery of hernia, 2nd ed., Baltimore, Williams \& Wilkins, 1967. I am grateful to Dr Colin G Thomas, Jr, Department of Surgery, University of North Carolina, for his advice and constructive comments. 


\section{Michael McVaugh}

tube - the didymus - uniting the peritoneal cavity and the cavity of the tunica vaginalis that surrounds the testicle. This model suggested to them that to correct an inguinal hernia it was necessary only to sever or destroy the didymus high up, towards the abdomen, so that when it healed the scar would block the channel breaching the peritoneal wall. As Theodoric Borgognoni explained, writing in the 1260s, the didymus could be severed in three ways. Two of these he described relatively briefly. In one, after reducing the hernia, the surgeon forces a heated cautery iron down through the skin at the spot where the hernia had been visible until the cautery is stopped by the pubic bone; in the other-designed, Theodoric says, "for the many who fear the knife and have no less abhorrence for the fire"-the surgeon applies corrosive medicines (for example, quicklime) to the same spot, over and over again, which will eat away the tissues until the pubic bone is reached. In both cases the expectation was that the procedure would encounter the didymus as it did its damage and would destroy it, sealing the passage through the inguinal ring by cicatrization. Theodoric's description of a third procedure is much more circumstantial than the other two, which suggests that this was the one in commonest use in the thirteenth century: the patient is tied to a plank, with his hips elevated and his head low; the surgeon cuts down to the didymus, frees it from surrounding tissue, ties it off, and severs it below the ligature, removing the testicle. Again, once the wound has healed, the intestine will no longer be able to escape. ${ }^{7}$

Let me emphasize that what gave surgeons confidence in these procedures was their conviction that the underlying anatomy ensured that they had to succeed. That is, once the treatment of hernia was definitively understood as a mechanical problem of blocking an opening, their approach was the only one assured of success; physicians could not cure it with drugs. Bruno Longoburgo wrote his surgery just before Theodoric, when the anatomical model was not quite established and when some

\footnotetext{
${ }^{7}$ Theodoric, Surgery, III.34; The surgery of Theodoric, transl. Eldridge Campbell and James Colton, 2 vols, New York, Appleton-CenturyCrofts, 1960, vol. 2, pp. 100-2. Bruno's Surgery, II.10, repeats the first of these treatments verbatim, but omits any account of the use of the potential cautery (Susan P Hall, 'The Cyrurgia magna of Brunus Longoburgensis: a critical edition', D Phil thesis, Oxford University, 1957, pp. 279-80), and in this it follows Albucasis, who discussed the actual but not the potential cautery in cases of inguinal hernia (Albucasis on surgery and instruments, ed. M S Spink and G N Lewis, Berkeley, University of California Press, 1973, pp. 134-9; ch. 45). The earliest reference I have so far seen to this application of the potential cautery is in a commentary on the Surgery of William de Congenis of Montpellier, in the first half of the thirteenth century: William's text speaks of cutting down to the didymus with a knife, but his student-commentator adds that once he saw him apply a corrosive medicine instead-“"sed cum aliquantulum corrosisset in profundum, homo dolorem sustinere noluit et sic magister in cura
}

non processit" (Karl Sudhoff, Beiträge zur Geschichte der Chirurgie im Mittelalter, 2 vols, Leipzig, J A Barth, 1914-18, vol. 2, p. 370).

Uniquely among thirteenth-century practitioner-writers, Theodoric Borgognoni was a cleric in major orders, at the papal court in the 1240 s (papal chaplain and penitentiarius) and a bishop from 1262 until his death in 1298. As such, as Darrel Amundsen has made clear, his surgical practice (though not that of the other lay figures mentioned here) should have been proscribed by canon 18 of the Fourth Lateran Council, at least any procedure involving burning or cutting: see D W Amundsen, Medicine, society and faith in the ancient and medieval worlds, Baltimore, Johns Hopkins University Press, 1996, pp. 235-9. But there is evidence to show that Theodoric's continued practice was sanctioned by the pope, informally if not formally, at least up to and perhaps after his appointment as bishop: see the texts published by Davide Giordano, 'Ancora sulla identità di Teodorico', Rivista di Storia delle Science Mediche e Naturali, 1930, 12: $135,136$. 


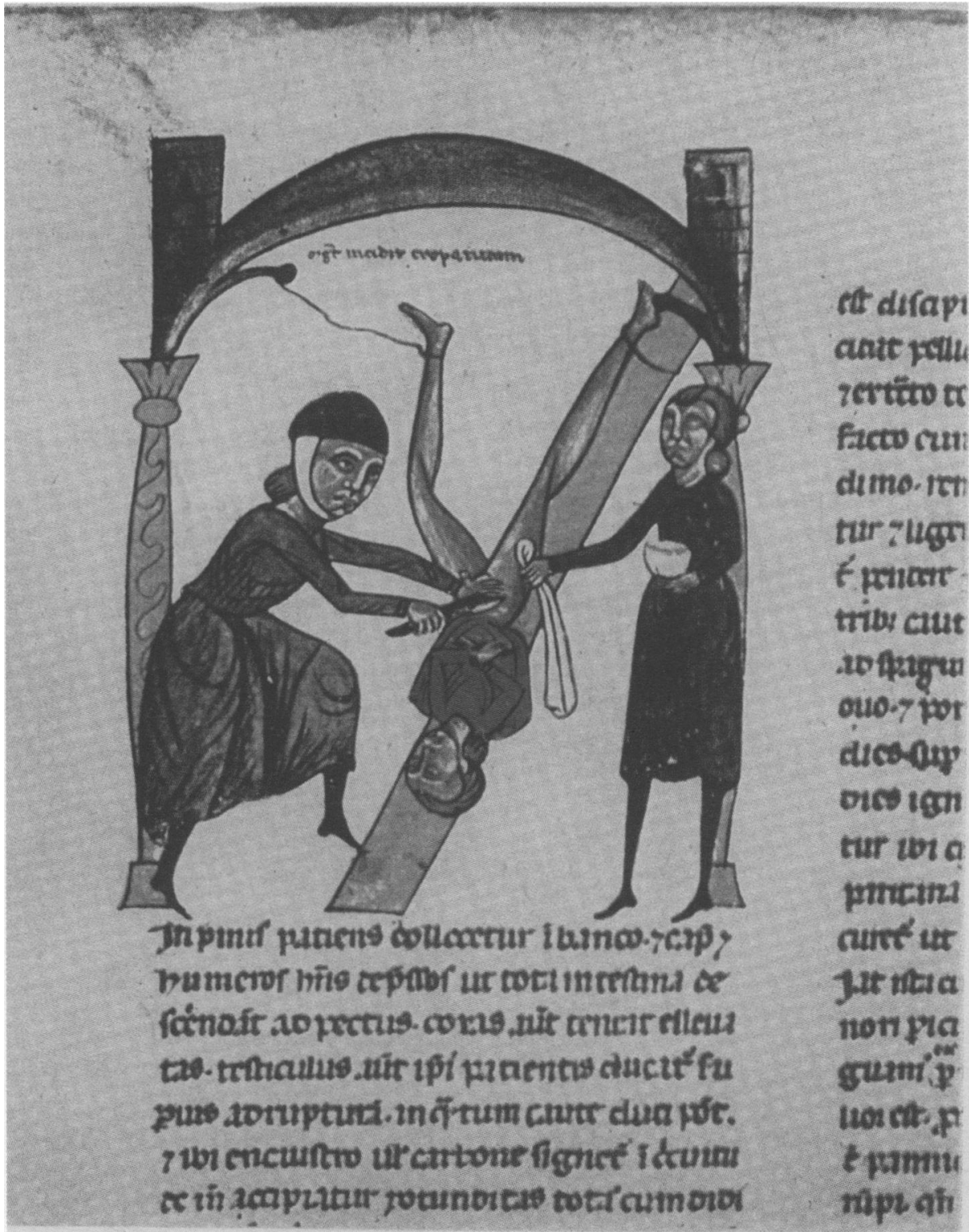

Figure 1: Treatment of inguinal hernia by surgical operation. Illustration in 'Chirurgia' by Rolandus Parmensis, MS 1382 (A.II, 15), Biblioteca Casanatense, Rome (photo: L MacKinney, taken for his Medical illustrations in medieval manuscripts, London, Wellcome Historical Medical Library, 1965).

physicians seem still to have imagined that hernias could be treated medically, but Bruno is dubious about this: at most he is willing to concede that this is possible when the hernia is small and recent and the patient is young-by poulticing a boy's 


\section{Michael McVaugh}

groin with a mixture of sticky gums that can penetrate the body and bind the aperture together, ordering him to stay in bed for 40 days, and enjoining him not to cough or sneeze. Actually, Bruno goes on, wise women (mulieres sagaces) sometimes treat the condition in their children with nothing more than a truss; ${ }^{8}$ but he concludes, "anybody who says he can cure a major chronic hernia just with medicines, whatever the patient's age, is a fraud".

Now while surgical writers recognized that their procedures were feasible, and recognized too that inguinal hernia could be fatal ("I have already seen two men die from this [condition]", wrote Theodoric), ${ }^{10}$ they knew quite well that their treatment could be just as dangerous as the hernia itself: "The patient often becomes seriously ill and can die easily", says Bruno, "so do not presume to undertake this treatment, thinking of the money you will get, unless the patient and his friends beg you to". ${ }^{11}$ Our writers recommend that the operation should be performed only after explaining the risks fully and candidly to the patient, before witnesses, and then only if the surgeon "has performed the operation before or has assisted a knowledgeable surgeon in it or has seen such an operation performed on someone, and is able and intelligent, since it is easy to kill the patient with an incompetent procedure, even though it may be grounded in science [edoctam]". ${ }^{12}$ No doubt moral scruples made some surgeons hesitant to perform dangerous operations, but here thirteenth-century confessors offered reassurance: "if [a surgeon] believes for solid and highly probable reasons that he can cure [a patient], as long as he omits nothing necessary we say that he has carried out the proper treatment". ${ }^{13}$

A painful, embarrassing, possibly life-threatening condition was made to order for the unsupervised, competitive, rapidly expanding craft of surgery as it existed around 1300. As Bruno's remark just quoted implies, sufferers were indeed willing to pay large sums for a treatment. Established surgeons such as Lanfranc of Milan,

\footnotetext{
${ }^{8}$ Bruno, op. cit., note 7 above, pp. 278-9.

9 "Qui ergo dicunt se sanare rupturam magnam et diuturnam et in omni etate cum modis medicinarum deceptores sunt" (ibid., p. 275).

${ }^{10}$ Theodoric, Surgery, III.35, transl. Campbell and Colton, note 7 above, vol. 2, p. 103.

11 "Multotiens accidit super infirmum malitia magna et moritur de facili; quapropter, amice, non est presumptio ut accipias hanc curam cupiditate lucri nisi quando rogatus es ab infirmo et amicis suis. .. . Et non oportet ut senex medicetur sive curetur curatione ferri, immo sufficit ut custodiatur cum braccali et dieta" (Bruno, op. cit., note 7 above, pp. 282-3).

${ }_{12}$ The quotation paraphrases William of Saliceto: "si usus fuerit tali operatione vel usus fuerit cum aliquo operatore rationabili vel viderit talem operationem fieri in aliquo et fuerit boni ingenii et bone ymaginationis secure potest in tali cura procedere; et per aliam viam non in hac cura presumat se aliquo modo operari quia per malam etiam edoctam operationem de levi
}

hominem interficere posset" (Chirurgia I.44, MS Oxford, St John's College 76, fol. 23r). For the importance of delivering a warning in front of witnesses, see Theodoric, Surgery, III.35, transl. Campbell and Colton, note 7 above, vol. 2, p. 103. Saliceto's procedure is essentially the same as Theodoric's, except that he ties the didymus with two ligatures a finger's-breadth apart "et illud spacium scindatur per medium ex transverso et postea cauterizetur optime" (ibid.).

${ }^{13}$ If a surgeon worries that his actions may have led to a patient's death, "ubi credit se per vera et valde probabilia argumenta eos posse curare ... tunc si nichil omiserit de contingentibus dicemus eum debitam curam apposuisse": Robert Courson, Summa de sacramentis (1204-8), in V L Kennedy, 'Robert Courson on penance', Mediaeval Studies, 1945, 7: 322-3. This rule applies not only to surgery; Courson responds to a physician's imagined concern in the same way. I am grateful to an anonymous referee for drawing my attention to this passage. 


\section{Aspects of Surgical Practice in the Fourteenth Century}

in the generation after Bruno and Theodoric, complained about the greed that characterized their unskilled and untrained competitors, who claimed to be able to cure inguinal hernia without using the knife and without damage to the testicle: "Many people", Lanfranc declared, "rashly attempt this treatment knowing nothing of the anatomy ... and continually go wrong in operating, but they do not learn from their mistakes; rather, the less they know, the more operations they perform". ${ }^{14}$ He himself was unhappy with surgical intervention for hernia, and urged conservative treatment instead, with bandages and a truss: the condition may not be cured in this way, Lanfranc wrote, but it will not get any worse, and the patient will not live one day less.

Yet Lanfranc's stories about his own practice suggest that he had to work hard to convince his patients that it would be better for them to endure discomfort for a lifetime than to risk everything for the chance of a permanent cure, especially when, as he complains, "empiric" practitioners were prepared to give them the operation they wanted. His account of his "empiric" competitors' methods makes plain that, notwithstanding his criticism of their lack of anatomical knowledge, they accepted the same anatomical model of the didymus that he did. In fact, some "empirics" put that model to use to justify offering an operation that, by scarring around the didymus without destroying it, would not damage testicular function, which every patient worried about; so in self-defence, therefore, even a deeply sceptical practitioner such as Lanfranc had to offer a similar operation in order not to lose patients to potential competitors. All that really set him and them apart from one another were the different techniques that each practitioner devised, like a personal advertisement, for severing or scarring around the didymus. The anatomical construction of hernia had established the condition as the province of surgeons rather than physicians, but this did not exclude empirics from treating it; once it had been acknowledged as a mechanical problem to be solved mechanically, skill and variation in manual technique came to be valued in practitioners more than mastery of anatomical detail, and in these technical factors "empirics" could be indistinguishable from the self-styled "surgeons".

\section{The Treatment of Cataract: Surgeons between "Empirics" and Physicians}

The history of response to the second health problem, cataract, shows how in other diseases medieval surgeons might be forced to divide the supervision of patients with physicians, disadvantageously. Specifically, it shows how a physiological interpretation of cataracts allowed physicians to claim control over aspects of the condition from which they could only profit, whatever the outcome, and forced

\footnotetext{
14 "Nam multi de hac cura se cum audacia intromittunt qui nec loca noverunt nec aegritudinis differentiam cognoverunt, quare quotidie cadunt in suis operationibus in errorem, nec propter hoc ab eorum insania se divertunt.
}

Sed quanto minus sciunt, tanto magis de curis se talibus intromittunt" (Lanfranc, Chirurgia, in Ars chirurgica Guidonis Cauliaci, Venice, 1546, fol. 241ra). 


\section{Michael McVaugh}

surgeons into anatomy-based treatments that narrowly restricted their therapeutic options, while still leaving them open to competition from empirics.

Unlike hernia, cataract was a condition ignored by the earliest surgical writers of the High Middle Ages, and there is no good evidence that it was diagnosed and treated before the thirteenth century. A famous twelfth-century illustration that has often been taken to depict an early operation for cataract may instead represent cosmetic treatment for albedo, a whitish spot on the cornea. ${ }^{15}$ In fact, neither Roger Frugardi's Chirurgia nor Roland's commentary pays much attention to conditions involving a loss of sight of any kind; they mention only pannus, film over the eye, which they both say is to be treated with medicines rather than the knife. ${ }^{16}$

Then, with the commentary of the Four Masters, written some time after 1250, we get a new sense that surgical writers were beginning to distinguish among various ways in which the sight could be obscured:

Under "pannus" [the Masters wrote] Roger means to consider ungula, macula, and catharacta. Pannus proper arises from a viscous humour that clings to a part of the eye and turns into a film that can be separated with a fine hook and cut off with a lancet... . Catharacta, [on the other hand,] ... arises from humours flowing into the space between the crystalline and aqueous humours [of the eye], and it is sometimes curable and sometimes not. ${ }^{17}$

Cataract, I might point out, is being given a physiological interpretation here, not (like pannus) a purely anatomical or mechanical one.

There are signs of interest in cataract as a new pathological entity in medical as well as surgical works from this period, around 1250: in the medical Compendium medicine of Gilbertus Anglicus, for example, as well as in Bruno's Surgery. These authors were apparently responding to discussions of cataract in the recently translated Arabic medical literature that was just beginning to circulate - translations by Gerard of Cremona in particular. Gilbertus makes occasional references to Avicenna's

\footnotetext{
${ }^{15}$ This is the argument of Mirko D Grmek, 'Albule oculorum: cataracte ou taies de la cornée?', in Deroux (ed.), op. cit., note 5 above, pp. 422-33.

${ }^{16}$ Rogerii Chirurgia, I.26, in Collectio Salernitana, ed. Salvatore di Renzi, 5 vols, Naples, Filiatre-Sebezio, 1852-9, vol. 2, pp. 442-3.

17 "Consequenter determinat actor de panno, per quem intelligit ungulam, telam, maculam, catharactam. Macula autem est passio que provenit in corona oculi in perforatione uvee tunice... Albugo autem est macula inveterata. Pannus quidem provenit ex humore viscoso in aliqua parte oculi adherente et in substantiam panni transeunte, et iste pannus cum unco subtili potest elevari et cum cultello abscindi. Ungula vero est que ab uno angulo oculi ad alium transit et fit ex eodem humore ex quo pannus et aliquando apparet extra substantiam oculi; ista
}

autem ungula sicut pannus curatur... .

Catharacta quidem provenit ex humoribus reumatizantibus, id est fluentibus ad oculos, et isti aliquando fluunt ad locum illum qui est intus cristallinum humorem et vitreum et faciunt catharactam, et in cura quidem istius catharacte non competunt exterius apposita, sed medicine interius sumpte, sicut pillule auree acuate cum esula, vel cum pillulis sine quibus esse nolo... . Item quandoque fit catharacta propter humores fluentes ad locum qui est inter cristallinum humorem et albugineum, et ista quandoque est curabilis, quandoque non, quod sic dinoscitur: patiens claudat oculum sanum et modicus diu fricet cum digito super palpebram oculi infirmi, postea patiens oculum suum aperiat subito, et si post diuturnam fricationem pupilla videbitur dilatari, signum est curationis; si vero non dilatatur, est incurabilis" (Glosulae quatuor magistrorum, in ibid., vol. 2, pp. 668-9). 


\section{Aspects of Surgical Practice in the Fourteenth Century}

Canon, ${ }^{18}$ while Bruno's account of cataract turns out to be drawn from Rhazes, Albucasis, ${ }^{19}$ and Haly Abbas, whose description of couching a cataract Bruno adopts almost verbatim. ${ }^{20}$ These Arabic sources are reflected in the very name the Latin authors use for the new entity. The Arabs interpreted it as a humoral overflow from

\begin{abstract}
${ }^{18}$ Gilbertus' account of cataract seems to me markedly confused, as if produced in the earliest stages of Western attention to the condition: "Ungula egilopa cataracta macula species sunt panni, et ex eisdem causis habent fieri et eisdem curantur. .. . Cataracta habet fieri ex humore collecto inter tunicas, alio modo dicitur sanguis replens venas oculorum et precipue coniunctive, unde dicitur a caracteribus" (Gilbertus Anglicus, Compendium medicine, 'De speciebus macule', Lyons, 1510, fol. 135ra). The treatments he prescribes are all for macule in general-none is mentioned as for cataract specifically, not even his statement that in some cases "acu torta immissa per caprinum angulum aut extrahatur aut inferius replicetur" (fol. 137ra). The overall appearance is of sources still incompletely assimilated. See also Henry E Handerson, Gilbertus Anglicus: medicine of the thirteenth century, Cleveland, Ohio, Cleveland Medical Library Association, 1918, p. 35; and, on Gilbertus' sources, L M Eldredge, 'The anatomy
\end{abstract} of the eye in the thirteenth century', Micrologus, 1997, 5: 145-60 (at pp. 153-4), and Ortrun Riha, 'Gilbertus Anglicus und sein "Compendium medicine"', Sudhoffs Archiv, 1994, 78: 59-79 (at pp. 67-9). Riha discusses the surgical side of the Compendium briefly at pp. 74-5.

Cataract is treated at Canon III.3.4.18-20 ('De aqua'): Avicenna, Liber canonis, Venice, 1507; rpt. Hildesheim, Olms, 1964, fols. 216v-17.

${ }^{19}$ Rhazes discusses the condition and its treatment in Liber divisionum I.31 ('De aqua descendente in oculo'; Venice, 1508, fol. 63rb); and in Almansor IX.27 ('De aqua descendente in oculum'; ibid., fol. 43va-vb). By far the most detailed account of the treatment for cataract, however, and the most important for Latin surgeons, was that given by Albucasis in Chirurgia II. 23 ('De curatione aque descendentis in oculum'), and it is worth quoting his description of the procedure: "Oportet ut facias sedere infirmum inter manus tuas quadratum oppositum lumini prope solem et liga oculum eius sanum et stringe eum valde, deinde palpebram oculi eius manu tua sinistra si oculus in quo est aqua est oculus sinister aut manu tua dextra si est oculus dexter, deinde accipe manu tua dextra almagda si oculus est sinister aut manu tua sinistra si oculus est dexter, deinde pone extremitatem almagda prope coronam per crossitudinem radii in ipsa albedine oculi a parte lacrimalis minoris, deinde impelle almagda cum virtute; et tu revolvis cum eo manum tuam donec penetres in albuginem oculi, et sentias quod almagda iam pervenit ad rem vacuam, et oportet ut sit mensura itineris almagda ad profundum mensura spatii quod est a pupilla usque ad finem nigredinis et est corona oculi. Videbis enim os in pupilla ipsa visione oculi propter claritatem tunice cornee, deinde pone almagda usque ad locum in quo est aqua, deinde prime ipsum inferius vice una post aliam. Si igitur descendit aqua statim tunc infirmus videt illud super quod aperit visum suum statim et almagda in oculo suo deinde quiescat paululum. Si igitur ascendit aqua tunc depone eam secundo preter quod egrediatur alma $<\mathrm{g}>$ da. Quando ergo figitur et non ascendit, tunc extrahe almagda cum facilitate et tu revolvis cum eo manum tuam paulatim, deinde dissolue in aqua aliquid ex sale claro gemme et ablue cum eo oculum deintus, deinde pone extra oculum totum stupam aut lanam infusam oleo rosato et albumine ovi et liga cum eo oculum sanum. Nos autem et illi qui sunt nostri temporis ponimus super eum ciminum tritum cum albugine ovi... . Et apud complementum operis tui preparetur infirmo dormitorium decenter factum in quod dormiat super dorsum suum in domo tenebrosa et prohibeatur ab omnibus motibus et a tussi et pone cibum eius illud in quo lenitur natura eius et non moveat caput suum dextra neque sinistra omnino, et sit ligamentum secundum dispositionem suam usque ad diem tertium; deinde solue illud in illa domo tenebrosa et experire visum eius et fac eum videre res, deinde reduc ligamentum usque ad diem septimum; et non oportet ut facias illud in hora evacuationis aut post incisionem statim, immo oportet ut allevies illud propterea quod aqua ascendit velociter per aspectum vehementem" (MS Yale, Paneth, pp. 517b-18a; cf. the Arabic and English texts in Spink and Lewis, op. cit., note 7 above, pp. 252-6).

Albucasis' very full account is evidently based closely on that provided by Paul of Aegina; cf. The seven books of Paulus Aegineta, transl. Francis Adams, 3 vols, London, The Sydenham Society, 1844-7, vol. 2, pp. 279-80. Paul's own work was unknown to virtually all medieval Latin medical authors.

${ }^{20}$ Haly Abbas, Regalis dispositio II.9.28, in Haly filius Abbas, Liber totius medicine, Lyons, 1523, fols. 278vb-279ra. 


\section{Michael McVaugh}

the brain into the eye and referred to it as al-mäa an-nāzil fi $\tilde{l}^{\prime}-{ }^{c}$ ain ${ }^{21}$ which most Latin translations rendered as "water descending into the eye"; so it was simply as "water", aqua, that many Western writers started referring to it in the later thirteenth century.

However, one influential translator of the late eleventh century, Constantine the African, had chosen to translate the Arabic phrase not as aqua but as cataracta, ${ }^{22}$ and it is worth wondering how he happened to light upon that particular word. Cataracta-from the Greek word for a something "falling down", anything from a sluice gate to a waterfall-is an exceedingly rare word in classical Latin, but it appears a dozen or so times in the Vulgate, where it refers to heavenly gates that allow waters to pour forth from the skies, not to the waters themselves. In only one very late antique writer is it used to refer (figuratively) to an eye disease: in Gregory of Tours, writing about 580, who used it in this way not once but on four occasions, most circumstantially in his account of the miracles of St Martin of Tours:

The deacon Theudomer had the openings of his eyes severely obscured for four years, after a flux of the head caused cataracts to descend. He sought out the cell where the blessed man [St Martin] had died and lay prostrate, unmoving, on his bed, spending the whole night praying and weeping; he wet the earth with his tears, and warmed the old wood of the bedframe with his sighs. Then, when day broke, the gates of his eyes lifted and he was allowed to see the light. Whenever did the physician's iron tools do anything comparable?- - tools that lead more to pain than to healing, and which, after the eye has been exposed and pierced with needles, seem to induce the torment of death more than they admit the light. ${ }^{23}$

My guess is that Constantine encountered Gregory's work in his reading as a

${ }^{21}$ Julius Hirschberg, Geschichte der

Augenheilkunde, Leipzig, Engelmann, 1899, rpt. Hildesheim and New York, Olms, 1977, vol. 1, part 2, pp. 176, 264.

${ }^{22}$ Pantegni, in Omnia opera Ysaac, Lyons, 1515, ii (practica), cap. 33: 'De cataractis oculorum' (fol. 121va).

23 "Theudomeris diaconus cum prae humore capitis, decedentibus cataractis, oculorum aditus haberet per quatuor annos graviter obseratos, venit ad cellulam Condatensem, in qua vir beatus transiit. Prostratusque ad ejus lectulum, nocte tota lacrymis et orationibus deducta, immobilis madefacit terram fletibus, tepuitque suspiriis ejus venerabile lignum cancelli; lucescente autem die, reseratis cataractis luminum, lumen videre promeruit. Quid unquam tale facere cum ferramentis medici, cum plus doloris negotium exerant quam medelae, cum distento transfixoque spiculis oculo, prius mortis tormenta figurent quam lumen aperiant? In quo si cautela fefellerit, aeternam misero praeparat caecitatem. Huic autem beato Confessori voluntas ferramentum est, et sola virtus unguentum" (De miraculis sancti Martini Episcopi II.19, in PL 71, Paris, 1849, cols. 949-50). Other instances of Gregory's use of the word are Hist. Franc. V.6, PL 71, col.
323; and Vitae patrum, $P L 71$, col. 1090, always in the phrases "decedentibus/decidentibus cataractis" or "reseratis cataractis". See Max Bonnet, Le latin de Grégoire de Tours, Paris, Hachette, 1890; rpt. Hildesheim, Olms, 1968, p. 219. The classical word for cataract was apparently "suffusio" (Celsus, De medicina VI.6; transl. W G Spencer, 3 vols, Cambridge, Mass., Harvard University Press, 1938, vol. 2, p. 222).

Where Gregory learned the term remains unknown, and I have not pursued the matter very far. It recurs in the ninth- or tenth-century "Sapientia artis medicinae" that is heavily dependent upon Greek terminology: "Cataractam sic cura: ... oculum eius sinistrum cum manu tua dextra paracintidas, oculum illius dextrum cum manu tua sinistra" (M Wlaschky, 'Sapientia Artis Medicinae; Ein frühmittelalterliches Kompendium der Medizin', Kyklos, 1928, 1: 103-13 [at p. 107]). We can perhaps postulate a late classical medical compendium as standing behind both. Gregory's knowledge of medicine is discussed by Edward James, 'A sense of wonder: Gregory of Tours, medicine and science', in Marc Antony Meyer (ed.), The culture of Christendom, London, Hambledon, 1993, pp. 45-60. 


\section{Aspects of Surgical Practice in the Fourteenth Century}

Benedictine monk, and that the word cataracta suggested to him that Gregory had been speaking of al-mā' an-näzil fíl l-'ain; this would have been reinforced by Gregory's implication that needles (spiculis) were being used by physicians to treat this condition in the sixth century. ${ }^{24}$ As I have said, Constantine's term "cataracta" had to compete with "aqua" in most thirteenth-century writings, ${ }^{25}$ and it did not begin to win out until about 1300; I suspect that it did so when Galen's book On symptoms and disease (De accidenti et morbo) began to be studied by Latin readers at the end of the century, because the book's translator had chosen to refer to cataracta rather than aqua, and its embeddedness in a systematic pathological framework gave the term a new authority. ${ }^{26}$ Shortly after 1300 the Montpellier physician Bernard Gordon underlined the equivalence of the old and new terms in his Lilium medicine: "water and cataract, the same thing [aqua seu catharacta, quod est idem]". ${ }^{27}$ But "cataracta" would still seem a puzzling word to King James of Aragon, twenty-five years later.

Many thirteenth-century authors had been equally puzzled as to what was meant by the unusual word cataracta, and they tried to work out their own etymologies on the basis of the Vulgate's use of the word to refer to physical gates or obstructions in the heavens. The surgeon William de Congenis probably had in mind the biblical passages suggesting that cataracts were heavenly gates that opened and shut when he spoke of optical cataracts as barriers that appeared "in the doorway of sight". ${ }^{28}$ But how to reconcile this physical explanation with the more physiological one implied by the name aqua? Arnald of Villanova used the confusion of names to illustrate a point of medical philosophy to his Montpellier students about 1300:

Names are often assigned to things [he told them] from their accidental properties: for example, just as the blockage of the pupil by water that has coagulated there unnaturally is called cataract because of its similarity to clouds in the sky or air. Hence to identify the right way of treating such an eye condition we must understand, not what it is called, but what it is.

\footnotetext{
${ }^{24}$ An extremely thoughtful and thorough discussion of the evidence bearing on the early history of Latin "cataracta" as referring to an eye disease, one unfortunately not available to me when this paper was composed, is Klaus-Dietrich Fischer, 'Die Klappe fällt-frühe Belege für cataracta als Bezeichnung einer Augenkrankheit', Medizinhistorisches Journal, 2000, 35: 127-47. In this paper Fischer identifies three other sources (besides Gregory and the Sapientia artis medicine) scattered between the fourth and ninth centuries that employ cataracta in this sense. This discovery obviously increases the likelihood that Constantine's use of the term derives from an awareness of the earlier Latin medical tradition, not from his reading of Gregory.

${ }^{25}$ Though Constantine's term was soon picked up at nearby Salerno, as in this terse account in Platearius' Practica: "Cataracte oculorum quandoque incurabiles, quandoque curabiles sunt. Curantur autem cum cirurgico instrumento scilicet cum acu sed solet recidivare passio. Dolet
}

enim locus et omnis dolor exacuit reuma, unde humoribus ad locum dolentem concurrentibus fit passio frequentius rediciva" (Johannis Platearii Practica, in Practica Jo. Serapionis, Lyons, 1525, fol. 209va-b).

${ }^{26}$ On the character and academic importance of the new De accidenti, see Luis García Ballester, 'Arnau de Vilanova (c. 1240-1311) y la reforma de los estudios médicos en Montpellier (1309)', Dynamis, 1982, 2: 97-158, esp. pp. 131-4.

${ }^{27}$ Bernard Gordon, Practica . . . dicta Lilium, Venice, 1498, fol. 4lra.

28 "De cataracta in porta visus" (Sudhoff, op. cit., note 7 above, vol. 2, p. 332). The Vulgate references are Gen. 7.11 and 8.2; Isa. 24.18; Mal. 3.10; and see also 2 Kings 7.2 and 7.19. The same idea-that the cataract is a physical impediment-is in Lanfranc: "dicitur cataracta per similitudinem illius instrumenti, quod est apud molendina, quod quando elevatur, currit aqua per canalem; quando deponitur, nihil currit" (Lanfranc, op. cit., note 14 above, fol. 238ra). 


\section{Michael McVaugh}

For when we know that this disease is a blockage of the pupil by coagulated water, this is enough to treat the condition properly, even if we do not know what name it goes by. ${ }^{29}$

William's physical interpretation and Arnald's more physiological one show us that by 1300 the newly defined cataracts were being understood both as mechanical obstructions to vision and as the coagulated product of a humoral pathology, and it is important to recognize, as in fact Arnald's statement implies, that their treatment was defined by the way in which they were understood. That is: they could be dealt with either medically, with drugs that would disperse the accumulation and coagulation of humours in the eyes; or surgically, with a needle that would "couch" or physically displace the cataract from the line of sight. This therapeutic dualism was reinforced by the standard treatments given in the Arabic sources that had first helped the Latin West identify cataracts: Albucasis' treatment is purely surgical, Rhazes' is heavily medical, while Avicenna and Haly Abbas discuss both kinds of therapy. We have here Owsei Temkin's two therapeutic perspectives embodied, curiously, in a single clinical entity. But in that case, whom should a patient seek out to treat this condition-a physician, or a surgeon?

To answer this, we must realize that cataract was thought of as existing in various forms and stages. I have already mentioned that the Four Masters believed that some cataracts could be cured and others could not. ${ }^{30}$ It may have been Galen's account of the physiology of cataract in De accidenti et morbo ${ }^{31}$ that led medieval authors to distinguish different hypothetical mechanisms that could produce cataract, now understood generally as a blockage of light by a flux of humours to the eye: the humours might turn to pus, or congeal, and block the pupil; or they might block the optic nerve, permanently and incurably - a form of cataract called gutta serena because it could not be seen in the pupil. This goes some way towards clarifying Princess Isabel's difficulties in getting treatment: I imagine that her Austrian doctors were still unsure whether her cataracts were of a curable kind.

\footnotetext{
29 "Nomina rebus sepe ab accidentibus imponuntur. Sicut oppilatio pupille que fit $\mathrm{ab}$ aqua innaturaliter ibi coagulata vocatur cataracta propter similitudinem quam habet cum nubibus celi seu aeris; ideo necesse est, ad inveniendum formam recte curandi talem passionem oculi quod cognoscat eam per diffinitionem et non per nomen tantum. Si enim sciverit quod passio eius est oppilatio in pupilla ex aqua coagulata sufficit ei ad recte operandum vel ad rectum opus dictandum, dato quod nunquam nominare eam sciret" (Arnau de Vilanova, Commentum super quasdam parabolas, 1.17, in Arnaldi de Villanova Opera Medica Omnia, VI/2, University of Barcelona, 1993, p. 161).

The two meanings had been more or less satisfactorily integrated by the time of Valescus de Taranta, at the beginning of the fifteenth century: "Notandum quod cataracta ... est equivocum ad 3... Uno modo est via subterranea per quam aqua sub terra discurrit; alio modo dicitur cataracta nubes vel discursus et motio pluviarum vel tonitrua; alio modo dicitur egritudo oculi de qua fit sermo. Nam ex primis 2
}

per similitudinem contrahit vocabulum ad significandum tertium. Nam sicut nubes vel aqua generatur ex vaporibus per ingrossationem in media regione aeris propter eius frigiditatem, sic cataracta in oculo a frigiditate cerebri vel oculi. Et sicut aqua per vias seu venas terre fluit a loco sue generationis usque ad oculum fontis, sic aliquando illa aqua descendit inter illas pelliculas usque ad oculum; ideo antiqui intitulaverunt cataractam hoc de aqua descendente. Sicut etiam nubes vel aqua in aere tollit radium solis, sic cataracta tollit radios et effigies rerum visibilium, ne ad locum pertingant visionis" (Valescus de Taranta, Philonium, II.29, Venice, 1521, fol. 36rb).

${ }^{30}$ The Four Masters suggest that the humours can accumulate either behind the crystalline humour (the lens) or in front of it, and can flow either between the lens and the vitreous humour, in which case they can be cured by drugs, or between the lens and the aqueous humour, in which case sometimes they can be treated and sometimes not. See above, note 17 .

${ }^{31}$ Galen, De accidenti et morbo IV.2, in Opera Galieni, Venice, 1490 , vol. 2, fols. 144rb-145rb. 


\section{Aspects of Surgical Practice in the Fourteenth Century}

But it could also be that her doctors were waiting to see how her condition evolved, for even the potentially curable form of cataract could be treated only at certain stages of its development. Bernard Gordon gives a good account of the picture that had emerged by 1300 or so: ${ }^{.2}$ watery vapours can descend from the brain and disturb the sight, collecting between the lens and the iris, in the opening of the pupil. At the beginning, when they first start to condense, the patient thinks he sees things like hairs and bugs (cimices) and flies and specks, and colours. ${ }^{33}$ At this point a cataract can be cured with medicines, by a physician; but once it is established and solid, only the surgeon can do it-and then not always, only when it is in what Bernard calls "an intermediate stage" ${ }^{34}$ For, as he goes on to explain, the second phase of coagulation is one that is too far advanced for the physician to treat but that is not yet solid enough for couching; subsequently it will coagulate enough to be couched; and ultimately, as the process continues, it will become too heavy to move. So the curable form of cataract starts as the concern of a physician, and only after he abandons the treatment does it pass to the surgeon, who himself has only a brief window of time in which to operate successfully.

I suggest that this division of labour was all to the physician's advantage. The physician ran no real risk with his patient's treatment: he restricted his diet, keeping him off watery foods like fish or fruits or soups that would increase the flow of watery vapours to the brain, purged him, and regularly applied a collirium of vegetable gums and animal gall to the affected eye-gall had been used to treat eye diseases ever since the angel Raphael recommended it to Tobias the son of Tobit. ${ }^{35}$ If the cataract did not show any improvement, the physician could not be blamed; from the medical or physiological perspective, illnesses are complex and are often controlled by hidden, individual factors, and may simply not respond to treatment. In contrast, the anatomical malfunction that the surgeon next had to treat seemed easier to visualize, seemed simpler to put right, so that a cure was expected of him-if he was any good. ${ }^{36}$ Henri de Mondeville complained that this gave physicians an unfair advantage by conceding them, but not surgeons, a kind of professional

\footnotetext{
${ }^{32}$ Gordon, op. cit., note 27 above, III.4.3 (fol. $41 \mathrm{ra}-\mathrm{b})$.

${ }^{33} \mathrm{Cf}$. Galen, op. cit., note 31 above (fol. 144vb): "Item si crossities illa non in uno loco sit coadunata sed dispersa circa hu. illum infirmus videnda quasi cimices et muscas esse putabit". Rhazes too refers to "cimices aut alia parva corpora subtilia et radiosa" in Almansor IX.27, note 19 above (fol. 43va). And cf. Galen, comm. Hipp. Prog. I.26, in Articella, Venice, 1523, fol. 147vb (I.23 in Kühn XVIIIb.73): "Fortasses enim est quod videt coram oculo simile capillo aut filis aut villis vestimentorum, et fortasse estimat homo quod volat coram oculis suis simile cimicibus aut muscis parvis, et fortasse est quod videt simile lenti aut grano milii nigri".

34 "In principio igitur curari potest a bono medico, sed post confirmationem non nisi per manum restauratoris, et etiam ab eo non semper, sed cum sunt in dispositione media" (Gordon, op. cit., note 27 above, fol. 41ra).
}

${ }^{35} \mathrm{Fel}$-gall-crops up repeatedly in medieval ointments for the eye, in part surely because of the angel Raphael's recommendation in Tobit 6. See, for example, the collyrium prescribed c. 1290 in the consilium by Taddeo Alderotti de opilatione nervi optici qui facit cataractam, which contained one ounce each of fellis yrci, vipere, fellis perdicis, fellis yrundinis, fellis asturis, fellis falconis, and fellis piscis marini mixed with an ounce and a half of gum and some celandine juice: Taddeo Alderotti, I 'Consilia', ed. Giuseppe Michele Nardi, Turin, Minerva Medica, 1937, pp. 10-11. Similar recipes can be found in Arabic sources: there is one, for example, in Rhazes, Almansor, note 19 above, IX.27 (fol. 43va).

${ }^{36}$ Similarly, surgeons complained, the apparent simplicity of surgical procedures encouraged patients to intervene in their own treatment: see Mondeville's comments in Julius Leopold Pagel, Die Chirurgie des Heinrich von Mondeville (Hermondaville), Berlin, Hirschwald, 1892, p. 114. 


\section{Michael McVaugh}

autonomy: "the surgeon has to perform manual operations, and any mistake in his treatment leaps to the eye or touch and is bound to be set down to him; but mistakes made by physicians are not obvious to the senses and can be ascribed to 'nature' or 'the governing force of the body." '37

How then does one know when the moment has come when a cataract is no longer to be treated medically but has become the responsibility of the surgeon? Bernard Gordon recommends a test that goes back to the Four Masters fifty years before, and beyond: ${ }^{38}$ rub the closed eye; then have the patient open it, and look at it quickly. If the pupil has not dilated, the cataract is too far gone, too hard, and cannot be operated on. If the pupil has dilated, good: in this case, if the water has been dispersed by the pressure, it is not yet solid enough to be couched; but if the cataract has returned to its original position, it is ready. ${ }^{39} \mathrm{~A}$ modern ophthalmologist would probably see this test as determining, not that a cataract was ripe for couching, but that the condition in question was cataract, for in even advanced cataract (unlike, say, glaucoma) some light passes through to the retina and activates the pupillary reflex ${ }^{40}$ By requiring the test before operating, medieval practitioners were unknowingly guarding against operating

37 "Habet cyrurgicus manualiter operari, et quia error hujus operis oculo et digito apparet nec potest alteri quam cyrurgico imponi, et error medici operantis sensui non apparet et potest imponi naturae et virtuti corporis regitivae" (ibid., p. 75).

${ }^{38}$ See the text cited in note 17 above. The test can be traced back as far as Paul of Aegina (see Seven books, note 19 above, vol. 2, p. 279), and Paul seems to imply that it can also be found in Galen, but I have not been able to identify a Galenic reference to the test. The Four Masters' account may be drawing on Haly Abbas, Regalis dispositio (note 20 above, fol. 279ra). The test is described rather differently in Constantine's Pantegni (note 22 above, fol. 121va): "ut oculos claudat infirmus precipe, deinde duobus pollicibus palpebram commove, et si subito apertis oculis aqua super pupillam fusa fuerit a pupilla separata nondum curandum intellige, si vero quasi calx coagulatissima incurabilis est".

${ }_{39}$ "Clauditur uterque oculus et tunc oculus infirmus cum pollice suaviter altero clauso manente fricetur et tunc celeriter infirmus oculus aperiatur et si pupilla non dilatatur nullo modo est subiicibilis quia nimis est confirmata. Si autem dilatetur et revertatur aqua ad pristinam dispositionem subiicibilis est et si remaneat dispersa adhuc non est confirmata et ita non esset subiicibilis" (Gordon, op. cit., note 27 above, fol. 41ra).

Gordon's account apparently represents a late stage in the evolution of this test; practitioners began by looking for the dilatation of the cataract and ended by looking for the dilatation of the pupil, as the following texts seem to show: Rhazes, Lib. div., note 19 above, I.31 (fol. 63ra): "Illa que ex ea curatur cum instrumento est que
... cum premis ea pollice tuo dilatatur, deinde redit et aggregatur"; William of Saliceto, Summa conservationis I.45, Piacenza, 1476, fol. [32]ra):

"Illa vero que ... dilatatur cum premis eam police tuo deinde redit et aggregatur ... curatur cum instrumento"; Bruno, op. cit., note 7 above, p. 202: "Compresseris cum pollice tuo palpebram interius ... et, aperto postea oculo, aqua videris separatam, deinde statim redit et agregatur, tunc similiter est curabilis"; Four Masters, in Collectio Salernitana, note 16 above, vol. 2, p. 669:

"Patiens claudat oculum sanum et modicus diu fricet cum digito super palpebram oculi infirmi, postea patiens oculum suum aperiat subito, et $\mathrm{si}$ post diuturnam fricationem pupilla videbitur dilatari, signum est curationis; si vero non dilatatur, est incurabilis"; Lanfranc, op. cit., note 14 above, fol. 238rb: "Leviter frica cum superiori palpebra oculum laesum cum palpebra illum claudendo et tunc subito illum aperias et vide si pupilla dilatatur ... tunc secure chirurgicum adhibeas instrumentum".

${ }^{40}$ Here and elsewhere in my discussion of cataract I am greatly indebted to the comments and advice of Dr James A Bryan III of Chapel Hill, NC.

Haly Abbas describes another test that would have the same effect: "Laudabilius autem adhuc ut patienti oculum claudere sanum imperes et ipsi manum superpone, tunc egrotantem aperi oculum in solis oppositionem. Et si oculi foramen videris dilatatum intelligas eiusmodi aquam excussionis admittere curam" (op. cit., note 20 above, fol. 279ra). Again, the narrowing pupil exposed to the sunlight is a sign that the loss of sight may be due to cataract, not necessarily that the cataract is ready for couching. 


\section{Aspects of Surgical Practice in the Fourteenth Century}

on conditions that were not cataract. A different kind of test described by Bernard, based on colour, more nearly matches what an ophthalmologist today might interpret as distinguishing an immature from a mature cataract. ${ }^{41}$

Let us now look closely at the details of the procedure, couching for cataract, as the first writers on the subject-Bruno and Saliceto and Lanfranc-understood it. We should acknowledge that probably none of them had performed the operation very often; these same writers were ordinarily eager to talk about their success with particularly difficult operations, ${ }^{42}$ yet they never refer to their own experience with cases of cataract. Nevertheless, they are not simply parroting their Arabic sources. It is clear that they have studied Albucasis carefully, because their outlines of the procedure generally follow his account rather closely, ${ }^{43}$ whereas their account of post-operative treatment tends to be modelled on Haly Abbas's. But each of our Latin writers also has his own variations on the common approach, as we will see, which suggests either that each is drawing on different sources that I have not yet identified, or that, however seldom they operated on cataract, each was beginning to develop-and to emphasize - a characteristic personal style or technique. Significantly, Bruno, who is the earliest of the three to describe the procedure, also has the simplest account.

To begin with, the patient is to sit facing the surgeon with his healthy eye shut. Bruno has the patient hold his own hand over it; Lanfranc bandages it shut, and adds that the surgeon should be seated higher than the patient. Lanfranc also adds the unexpected stipulation that the surgeon should now chew some fennel leaves, and should blow lightly into the patient's eye before beginning the operation so that it will get the benefit of the fennel vapour. ${ }^{44}$ Now, take a needle — of silver, and rather thick, so that it can be held, says Lanfranc; Saliceto contends, on the contrary, that a fine, smooth (tersa) iron needle is easier to hold-and introduce it into the eye on the inside in the white near the pupil ${ }^{45}$ you will be operating right-handed on the patient's right eye, left-handed on the left (thus angling down over the nose). You will feel the needle plunge into an empty space, and at this point move it towards the aqua (the lens); you will see the needle framed in the pupil. Press the needle down to move the lens out of the way, and

\footnotetext{
41 "Modus discernendi est iste cum autem in loco luminoso oculus bene respicitur; si color aque fuerit sicut color fungi aut calcis aut grandinis aut color niger fuerit, significatur quod nimis est indurata et non esset nimis subiicibilis; quare tunc non est laborandum.... Si autem color aque est aereus diafanus transparens vel quasi, tunc est subiicibilis" (Gordon, op. cit., note 27 above, fol. 41ra). Today cataracts tend to be classed as brownish or whitish, and the more colour they have the more mature and harder they are, as Bernard suggests, but there is no point at which they are too hard to be couched.

${ }^{42}$ See Nancy G Siraisi, 'How to write a Latin book on surgery: organizing principles and authorial devices in Guglielmo da Saliceto and Dino del Garbo', in Luis García-Ballester, Roger French, Jon Arrizabalaga, and Andrew Cunningham (eds), Practical medicine from Salerno to the black death, Cambridge University Press, 1994, pp. 88-109.
}

\footnotetext{
${ }^{43}$ Albucasis' account, in turn, comes from Paulus Aegineta, but medieval authors did not know this source; see Seven books, note 19 above, vol. 2 , p. 280 .

44 "Habeas in ore ramos foeniculi, quos mastices, et in oculo bis vel ter insuffla, ut fumus habens virtutem foeniculi oculum intret" (Lanfranc, op. cit., note 14 above, fol. 238rb).

${ }^{45}$ Bruno (op. cit., note 7 above, p. 203): in Hall's edition, "a parte maioris lacrimalis", but some manuscripts read "minoris", probably correctly, since Bruno is here quoting from Albucasis (see above, note 19). William of Saliceto (Chirurgia I.10, note 12 above, fol. 10v): "in medio albedinis ... usque ad medium oculi circa pupilli"; idem (Summa conservationis, note 39 above, fol. [32]ra): "in medio coniunctive usque ad palpebram". Lanfranc (op. cit., note 14 above, fol. 238rb): "in coniunctivam apud minorem angulum oculi”.
} 


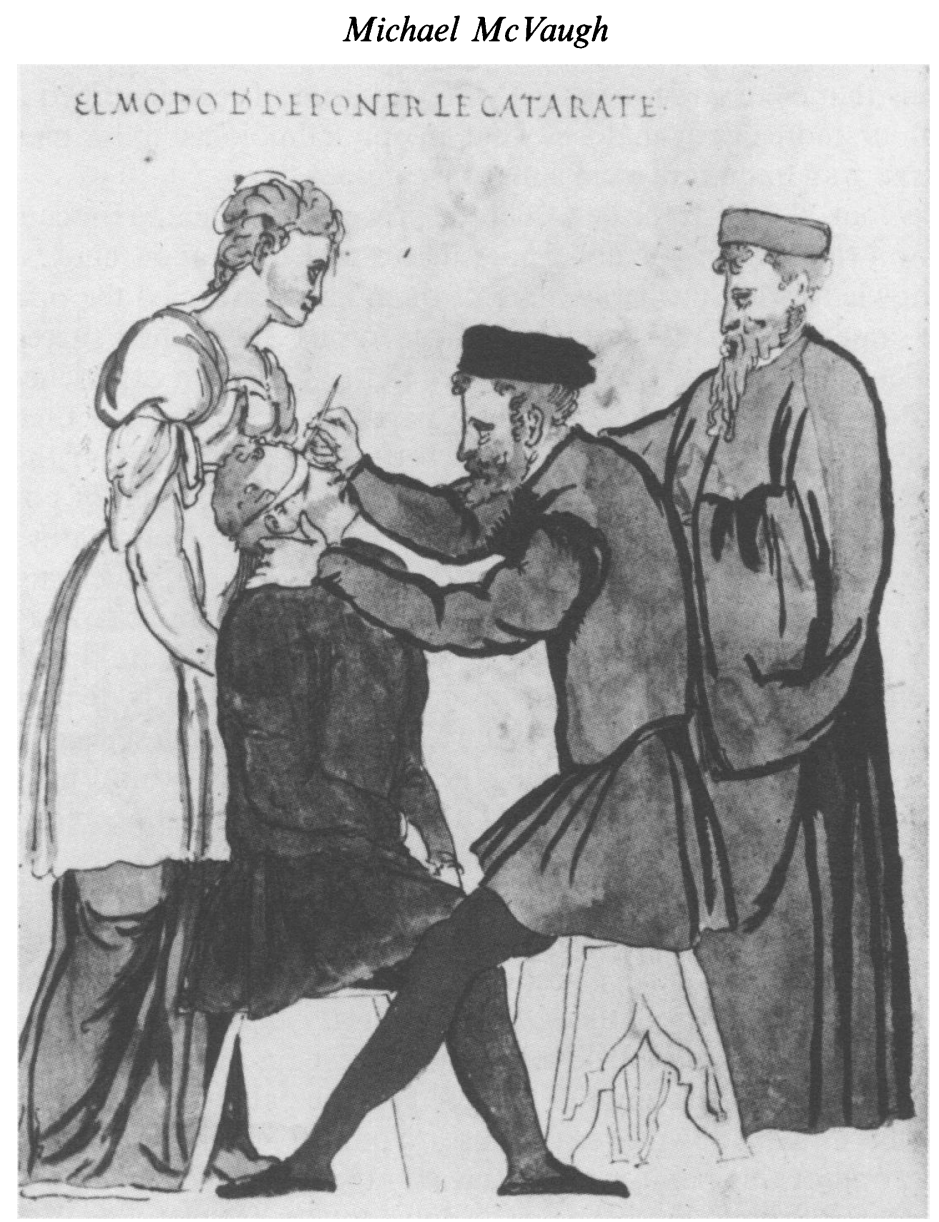

Figure 2: A late-medieval operation for cataract from a medical picture book by Henricus Kullmaurer and Albert Meher, BM MS Prints and Engravings 197.d.2 (c. 1510). (Trustees of the British Museum.)

if it returns, repeat the process until it stays down; then withdraw the needle. (This at least is what Bruno and Lanfranc say; Saliceto instructs the reader to keep the lens depressed for twenty minutes, and does not entertain the possibility that it might return.) Bruno follows Albucasis in next washing the eye with cumin water and sal gemma, whereas the other two omit this stage. All three writers conclude by putting a dressing on the eye soaked in rose water and egg white; Lanfranc adds Armenian bole to the mixture, whereas Saliceto adds camphor.

It is interesting that these accounts are not integrated at all well with these writers' earlier accounts of the eye's anatomy, suggesting that the new anatomical emphasis had not yet significantly affected practice. Their accounts of the eye's structure say nothing about its pathology, and their accounts of cataract are not related to their anatomical descriptions. When our authors speak of depressing the aqua, they do not identify this with the crystalline humour, and they do not talk about where it is 


\section{Aspects of Surgical Practice in the Fourteenth Century}

being pushed; nor are their works illustrated with anatomical diagrams. The surgeons' sense of the physical plan of the eye that they used as a basis for their manipulations was apparently still quite distinct from the anatomical description that they were so proud of: their practical and theoretical anatomies were evidently still separately compartmentalized. ${ }^{46}$

While our authors do not go on to spell out the dangers of the operation (for example, haemorrhage into the eye can cause sudden intra-ocular pressure and kill the optic nerve, destroying what limited sensitivity to light the patient may still have had), they are definitely unenthusiastic about the procedure. Saliceto is explicit that "no one can really learn this procedure unless ... he observes the operation with his own eyes; because the eye is so noble an organ, he must not dare to try it himself unless he has first seen someone else do it". ${ }^{47}$ Nevertheless, the operation was more or less forced on surgeons, just like the operation for hernia, because patients wanted it, believed it should work, and were willing to pay. John of Gaddesden reports about 1330 that "if a physician or a surgeon can treat this condition, he will earn huge sums, . . . because from one treatment of this kind he will draw more money than someone else would from treating ten cases of other diseases".$^{48}$ Yet the technical difficulty of the procedure, together with the high value people placed on their sight, meant that the surgeon was likely to fail in a situation where the importance of a cure was particularly high. Arnald of Villanova is reported to have said that although he had often seen practitioners try to couch a cataract, he had seldom seen a successful outcome. ${ }^{49}$

This must have left many practitioners torn between the pressure of the marketplace and their fear of a bad outcome. A student of William de Congenis has left a vignette of a scene at Montpellier in the later thirteenth century:

\footnotetext{
${ }^{46}$ Eldredge, op. cit., note 18 above, comes to very similar conclusions about the development of these theoretical anatomies, although he suggests that they reveal "the medical practice of a university physician who did not practice very much" rather than the surgeons'

compartmentalization of theory and practice.

${ }^{47}$ " $\mathrm{Hec}$ autem cura in veritate non potest disci nisi discipulus videat oculis propriam operationem super hoc; propter nobilitatem membri non est presumendum ab aliquo facere hanc operationem nisi prius videat aliquam coram eo eam fecisse" (Saliceto, Chirurgia, note 12 above, I.10). On the eye as a noble member and the precautions that that enforced on surgeons, see Mondeville, Surgery, notabilia 14 contingens 3; in Pagel, op. cit., note 36 above, p. 85 .

48 "Si medicus physicus, vel chirurgus, hunc morbum poterit curare, multas lucrabitur pecunias, quia saepe occurrit; et vidi ego cum acu operantes, qui miranda praestiterunt; unde illis honos habitus est, ut in una eiusmodi curatione, plus pecuniae reportarent, quam alius in decem curis aliorum morborum" (John of Gaddesden, Praxis medica Rosa anglica dicta, Augsburg, 1595, p. 183). Gaddesden's account of cataract is often little more than a paraphrase of Bernard
}

Gordon's discussion, which makes his intermittent personal observations on the condition and its treatment all the more striking.

49 “Aussi ne nous étonnerons pas si nous voyons Arnauld de Villeneuve constate que, s'il a vu souvent des spécialistes abattre la cataracte, rarement il a pu constater que cette opération ait donnée des résultats heureux" (P Pansier,

Collectio ophtalmologica veterum auctorum, Paris, Baillière, 1903-33, fasc. VI, p. 108; also published by idem, 'La pratique d'ophthalmologie dans le moyen-âge latin', Janus, 1904, 9: 3-26 [at p. 14]; unfortunately, Pansier does not identify the source of his reference).

It may be relevant to point out that although Rhazes referred to the operation for cataract in his Liber Almansoris and Liber divisionum, he himself declined the operation in his old age: "AlRãzĩ was a contemporary of Hunain ibn Ishăq and those who were with him at that time. $\mathrm{He}$ became blind at the end of his life as a result of water which fell in his two eyes. He was told, 'If only it could be pierced!' He said, 'No, I have seen enough of this world as to be bored with it.' He refused to have his eyes pierced" (Ibn abi Usaibica, 'Cyūn al-Anba', 3rd ed., Beirut, 1981, p. 350). I owe my knowledge of this passage (and its translation) to the kindness of Dr Henry Azar. 


\section{Michael McVaugh}

At Montpellier I saw someone operate on Otto de Stadio's eye for cataract. The procedure went smoothly but it was not successful because, so he claimed, the cataract had not solidified enough yet to be couched. So the patient was left unable to see [what little] he had been able to see just before [this may have been an instance of intra-ocular haemorrhage], and the operation ended up a disaster. ${ }^{50}$

I doubt that the surgeon's excuse - that the cataract had not been ready for couchingdid much to satisfy the patient, because after all it was the surgeon's responsibility to define the moment when it was operable. No doubt it was outcomes like this that led Lanfranc to say, if the patient can see anything in the eye with the cataract, do not operate ${ }^{51}$ - but it was difficult to hold off an eager patient when other practitioners were prepared to take the money, operate (mocking more cautious operators for their hesitation) $)^{52}$ and run.

The anonymous student went on to reflect on precisely this point, the competitive disadvantage that some surgeons faced in treating cataract:

The practitioners who travel from town to town and never stay in one place do better with this procedure than famous surgeons [cirurgici famosi] do because they perform it so often; but before they master the technique they injure a lot of people. ${ }^{53}$

The "famous surgeons" are men such as Lanfranc, and they clearly had to worry about the competition of empirics over the treatment of cataracts, just as they did with hernias, for again the anatomical basis was straightforward, and technical facility rather than the anatomical learning they boasted was therefore going to be the crucial factor in the patient's choice of an operator. Empirics had no compunctions about the difficulty of the operation; if it failed, as our student complains, they were not members of the local community and would not have to stay around to confront the consequences-and yet over time they could profit from their failures and become increasingly dexterous. ${ }^{54}$

Perhaps it is natural that we today should tend to identify with these surgeons against the "empirics" they condemned. Because we share the view that the surgeons were promoting, that surgery should properly be dependent upon medical science,

\footnotetext{
50 “Ad montem Pessolanum ... vidi quendam operantem circa cataractam in oculo domini Ottonis de Stadio. Bene quidem operabatur, sed non profecit, quia, sicut ipse dixit, adhuc non fuerat satis coagulata cataracta, ut deprimi posset. Unde nec ex hoc aliquid vidit, sicud fieri solet statim, et ita labor talis perdibus fuit" (Sudhoff, op. cit., note 7 above, vol. 2, p. 331).

51 "Considera igitur quoniam si aeger aliquid ex oculo videt, manum non ponas" (Lanfranc, op. cit., note 14 above, fol. 238ra-rb).

${ }^{52}$ Lanfranc replied angrily to such taunts: "O quoties quidam volentes me mordere dente canino de me tales curas dimittente dixerunt, quod ego curas illas dimittebam quia curationis magisterium ignorabam. Hoc idem dicebant de ruptorum incisionem et hidropicorum, quorum curam propter pericula dimittebam; et de cataracta deponere, quas dimisi non ut modum depositionis ignorarem, sed quia pericula in opere illo saepe contingunt, per quae etiam boni
}

perfectique medici diffamantur" (ibid., fol. 245va).

53 "Nota autem cirurgici qui discurrunt de villa ad villam et nusquam faciunt residentiam, in huiusmodi curis melius operantur, quam cirurgici famosi, et hoc propter fraequentem usum. Sed antequam iste usus eis acquiratur, multos destruunt" (Sudhoff, op. cit., note 7 above, vol. 2, p. 331).

${ }_{54}$ The complaint long outlasted the Middle Ages. Pieter van Foreest (1522-97) described an empiric's botched cataract operation he had seen and went on to say angrily that "sunt multi oculistae qui per urbes vaguntur et fraudulenter agunt, pecuniam extorquentes ab aegrotantibus, multaque promittentes quae tenere non valent" (quoted by L M Eldredge, 'The English vernacular afterlife of Benvenutus Grassus, ophthalmologist', Early Science and Medicine, 1999, 4: 149-63 [at pp. 157-8]). 


\section{Aspects of Surgical Practice in the Fourteenth Century}

we tend to imagine the medieval "empiric" as unprofessional, untrained, and therefore incompetent. Moreover, if empirics were unlearned, we inevitably imagine them as illiterate, at least in Latin, and this further reinforces our sense of their inferiority to writers like Saliceto or Lanfranc. But we need to cast these prejudices aside, for the specialized Latin ophthalmological treatises that survive from the later Middle Ages are actually the works of these same despised empirics, not of a subset of learned surgeons.

A remarkable example of this genre is the late thirteenth-century De probatissima arte oculorum of Benvenutus Grassus. ${ }^{55}$ This work begins with a simple account of the anatomy and physiology of the eye that is followed by a discussion of twentyodd eye diseases and their treatment, among which cataract comes first. Benvenutus describes a procedure of couching for cataract that is essentially identical with that of the learned tradition: the patient sits facing the surgeon and covers his own eye; the operator uses a gold or silver needle (not iron, which is too fragile, Benvenutus explains), with which he pierces the eye at its outer corner rather than inner; and applies egg white afterwards. ${ }^{56}$ Benvenutus evidently shared the assumptions, the approach, even the terminology of contemporary surgeons like Saliceto, yet he appears to have been ignorant of their writings, for De arte never refers to that tradition or seems to echo its language (and in turn De arte is not quoted by surgeons before Jean Yperman, in 1328). ${ }^{57}$ Indeed, aside from his use of Latin, Benvenutus shows virtually no sign of academic exposure. He appears to quote once from the most basic of medical texts, Johannitius' Isagoge, but he refers only vaguely to Galen and Hippocrates, giving no sign that he knows any of their works, nor is there any trace in his treatise of the Arabic surgical authorities so popular in his day, Avicenna and Albucasis and Rhazes. We can believe that he was, as his treatise tells us, merely a travelling eye specialist, whose practice had taken him from Tuscany to Rome, from Sardinia to Sicily, and even to North Africa. ${ }^{58}$ Benvenutus' work forces us to acknowledge that the wandering "empirics" so vilified by the surgical writers could themselves be men of considerable understanding as well as skill. ${ }^{59}$

It was just such a wanderer who treated Gilles le Muisit, abbot of St Martin in Tournai, in 1351, three years after he went blind. The abbot made a record of the experience:

A German master came through Tournai, and after he looked at my eyes he promised he

\footnotetext{
${ }^{55}$ See the study by $\mathrm{L}$ M Eldredge, Benvenutus Grassus, The wonderful art of the eye: a critical edition of the Middle English translation of his De probatissima arte oculorum, East Lansing, Michigan State University Press, 1996. A version in more recent English is available in Casey $\mathbf{A}$ Wood, Benevenutus Grassus of Jerusalem, De oculis eorumque egritudinibus et curis, Stanford University Press, 1929.

${ }^{56}$ A summary of the operation is conveniently available in L M Eldredge, 'A thirteenth-century ophthalmologist, Benvenutus Grassus: his treatise and its survival', J. R. Soc. Med., 1998, 91: 47-52 (at pp. 48-9).

${ }^{57}$ Eldredge, op. cit., note 55 above, p. 4.

${ }^{58} \mathrm{~L} M$ Eldredge, 'The textual tradition of Benvenutus Grassus' "De arte probatissima
}

oculorum"', Studi medievali, ser. 3, 1992, 34: 95-138, at pp. 95-6.

${ }^{59}$ Benvenutus himself was often highly critical of other, incompetent eye surgeons: see Eldredge, pp. $53-4,61$, or Wood, pp. 32,43 , both note 55 above. Occupying an occupational niche rather like Benvenutus'- though a hundred years later, and in a very different specialization (fistular and genito-urinary surgery)-is John of Arderne, who, though outside the learned tradition, drew heavily upon that tradition in his writings and tried to distance himself from mere barbers and women (domine). See Peter Murray Jones, 'John of Arderne and the Mediterranean tradition of scholastic surgery', in García-Ballester et al. (eds), op. cit., note 42 above, pp. 289-321. 


\section{Michael McVaugh}

could cure me, with God's help. Having thought over all he had told me, in the end-against the advice of my family and friends-I accepted his offer, and on the Sunday after the exaltation of the Holy Cross [14 September] I let him work on one eye and the following Thursday on the other. He operated with a tool like a needle, restoring light to the eyes quickly and with little pain. I recovered my sight and could see-not like a young man, but as well as could be expected for the 80-year-old that I am-and I saw the sky, the sun, the moon, the stars (though I could not recognize people very well), and I could take care of myself pretty well except that I could not read or write. ${ }^{60}$

Just as in the case of hernia treatment, surgeons had to find some way of competing with empirics like this German one-hence, perhaps, the importance of the individual procedural variations mentioned earlier, which practitioners could emphasize in order to argue for the superiority of their own approach. Saliceto in the 1270 s felt that the procedure was so dangerous that it had to be learned by close apprenticeship-but despite that concern, at least some in the next generation of surgeons evidently felt pressure to acquire the technical skill on their own, as another remark by John of Gaddesden suggests: many surgeons do not dare to try the operation, he says, "because the body can be damaged by a shaky hand. This is why it is recommended that a surgeon prepare for the risk by piercing the eye of a dog or a rooster or another animal, so that he can learn how to introduce the needle directly in between the tunics, without any loss of fluid from the eye" ${ }^{61}$

\section{The Problems of Fourteenth-Century Surgery}

My contention, therefore, is that the surgeons' decision to stress an anatomical basis for their craft almost immediately had unintended consequences. They had meant to lay claim to their own specialized science in order to emphasize their kinship to physicians and their separation from empirics, but their campaign went wrong in both respects: their new anatomical orientation tended to distinguish them even more sharply from physicians in the kinds of diseases they treated and the kinds of care they offered, while it forced them despite themselves into a closer, if increasingly confrontational, relationship with empirics.

And looking further into their future, I find myself speculating whether their new

\footnotetext{
60 "Sic senescens visus meus cepit debilitare, et in fine non poteram bene scribere aut legere. Modo accidit quod anno $\mathrm{m}^{\circ} \mathrm{ccc}^{\circ}$ quadragesimo octavo ... obcecatus fui totaliter... . Modo sciant futuri quod quidam magister de Alemania venit in Tornacum et, visis oculis meis, promisit cum Dei adjutorio me curaturum. Consideratis omnibus que michi dixit, finaliter contra consilium propinquorum et amicorum meorum omnium ego acquievi ejus consilio, ita quod Dominica post Exultationem sancte Crucis [the feast day is 14 Sept.] in uno oculo et feria quinta sequenti in alio permisi in eis artem suam exercere. Qui cum parvo dolore et cito transacto cum quodam instrumento ad modum acus est operatus, discooperiens lumen oculorum. Visum recuperavi et vidi, non sicut in etate juvenili, sed sicut etas mea requirebat, quia jam eram
}

octogenarius, et videbam celum, solem, lunam, stellas, non perfecte cognoscens gentes, et in omnibus michi bene providebam excepto quod scribere aut legere non valebam" (Henri Lemaître, Chronique et annales de Gilles Le Muisit, abbé de Saint-Martin-de-Tournai [1272-1352], Paris, Renouard, 1906, pp. 306-7).

61 "Istam operationem nescit Chirurgus, nec Medicus Physicus (nisi prius opere ipsam viderit), atque ideo non audebit illam tentare, quoniam corpus laederet manu tremula. Quare consultum esset, ut Chirurgus prius faceret periculum, perforando oculum canis, galli, vel alterius animalis; tum id nimirum consequetur, ut acum directe sciat ponere inter tunicas, sine laesione humiditatis oculi" (Gaddesden, op. cit., note 48 above, p. 187). 


\section{Aspects of Surgical Practice in the Fourteenth Century}

orientation might have had other, long-range consequences: whether the direction surgeons seem to have begun to take at the turn of the fourteenth century did not lead gradually on to the occupational stratification of health care in the sixteenth, and the subordination of surgery to medicine. This possibility should be kept in mind as I turn to a mid-century episode: I began with a particular case, and I want to end with one.

In the 1330s, the Czech chroniclers tell us, King John of Bohemia began to call in specialists to treat his failing sight. A French practitioner summoned to Wrocław proved incompetent and by the king's command was tied up in a sack and dropped into the Oder. With his left eye now blind and his right eye dim, the king invited a Muslim practitioner to the court at Prague-but this one damaged John's right eye further and harmed a number of other clients; he would probably have gone into the Moldau if he had not prudently extracted a safe-conduct from the king before coming to Prague. ${ }^{62}$ Increasingly desperate, King John travelled to Montpellier about 1339, accompanied by his son Charles and a few others, to see if the practitioners there could help, but nothing they did was of any use, ${ }^{63}$ he returned to Bohemia entirely blind, though he could dissimulate so well that he convinced many people that he could still see.$^{64}$ When he died fighting with the French at the battle of Crécy, seven years later, he had to be strapped to his horse and pointed towards the noise the English were making. ${ }^{65}$

One of the practitioners who treated King John on his trip to Montpellier was Guy de Chauliac, the last and perhaps the greatest of the writers in the medieval surgical tradition I have been discussing. Guy had received a medical degree at Montpellier, and he deployed his medical learning ostentatiously to underpin the surgical instruction of his Chirurgia magna of 1363 . We know that he must have seen the king on the trip of 1339 because a quarter-century later, in his Chirurgia magna, he used King John's case to exemplify the treatment of cataract-which makes it clear what contemporary practitioners thought the king was suffering from.

You might expect that, as a surgical writer, Guy tried to couch the royal cataract. There is no doubt that he was familiar with the technique. He talks about his own

\footnotetext{
62 "Sub istius temporis curriculo Johannes, rex Boemie, se senciens in suis oculis, quos nunquam acutos habuerat, plerumque deficere, medicorum cepit auxilium pro acuendo visu in oculis advocare, quorum unus Gallicus in praxi illa deficiens ex mandato Johannis, regis Boemie, in Wratislavia in flumen Oderam sacco impositus est proiectus; quo extincto alter paganus de Arabia veniens vocatus per ipsum regem in Praga, multo illato regi martyrio cum verbo tamen consolatorio Johannem regem in dextro oculo penitus excecavit. Idem paganus, quia non solum regem, verum eciam multos per suam chirurgiam deceperat, extinctus quidem fuisset, si veniendi et recedendi eidem securitas per regem promissa certitudinaliter non fuisset" (Petra Žitavského kronika Zbraslavská III.14, Fontes rerum

Bohemicarum, 8 vols, vol. 4, ed. J Emler, Prague, Nákl. N F Palackého, 1884, p. 334).

${ }_{63}$ "[Carolus] venit abinde ad patrem suum, quem invenit in uno oculo totaliter defecisse et in
}

secundo oculo incipientem infirmari. Tunc rex Iohannes una cum filio transierunt cum paucis in Montem Pessolani, ut ibidem per medicos rex in oculis curaretur. Sed medicamina non profuerunt, et excecatus est rex Iohannes in utroque oculo et amplius non vidit lumen usque in diem exitus sui" (Kronika Beneše $z$ Weitmile, in Fontes, note 62 above, vol. 4 , p. 508).

64 "Simulabat se tamen idem rex videre, cum non videret, et multi, qui ipsum intuebantur, cecitatem ipsius non consideravere, quia omnia facta sua taliter disponebat, ut videre crederetur" (ibid., p. 488).

${ }^{65}$ Ibid., p. 514. On King John's medical history, see Emanuel Vlček, Jak zemřeli, Prague, Academia, 1993, pp. 70-104. Jiři Spěváček, Jan Lucemburský, Prague, Svoboda, 1994, pp. 530, $542-3$, discusses his blindness briefly. I am grateful to Dr Josef Anderle for translating the Czech for me. 


\section{Michael McVaugh}

personal preferences in operating - using an iron needle rather than one of gold or silver, ${ }^{66}$ puffing not just fennel vapour into the eye but garlic or anything acrid. ${ }^{67} \mathrm{He}$ describes the actual procedure in unusual detail,$^{68}$ and he tells surgeons how to finish for maximum dramatic effect in order to have their skill properly appreciated: "when you remove the needle, shade the patient's eye with his hood, make some gesture, just once, and ask, 'What was that?" "69 But in fact, Guy seems never to have set a needle to the king's eye. What he did instead was to recommend to the king a medical treatment rather than a surgical one, a regimen of diet and drugs that excluded moist, rude, heavy foods, apparently to play it safe: as he explains in the beginning of his chapter, "Do not be overconfident about treating cataracts, because medicines do little good and the use of the needle is really treacherous" ${ }^{70}$ In the case of the king, performing an unsuccessful surgical operation on his patient ran Guy the risk of being dropped into the Rhône; recommending a conservative diet ran him no risk at all.

Guy was, as I have said, the last of the great surgical encyclopedists of the Middle Ages, but I have begun to wonder whether we should call him just a surgeon. He speaks of himself as "cyrurgicus et magister in medicina", and in charters and in the rolls of the papal court he is called phisicus - physician rather than surgeon. ${ }^{71}$ And, given a degree of choice, as in the case of the King of Bohemia's cataracts, Guy opted to act as a physician rather than as a surgeon. ${ }^{72}$ I find myself speculating that with Guy we may have reached a moment in history when practitioners who combined surgical training with medical learning were beginning to give up on surgery, to assume the role of the physician and to leave surgery to the empirics; if they practised as physicians, they could expect to be conceded what I earlier called a kind of professional autonomy or authority, and their career would run fewer risks of disasters. Think of Guy and his decision to treat the king's cataracts medically rather than surgically: no doubt he expressed his regret for the professional failure when the royal eyes did not improve with a change of diet. I suspect I know exactly what happened to Guy de Chauliac after he acknowledged his failure: the king heard his physician out, accepted his apologies graciously ... and rewarded him handsomely all the same.

\footnotetext{
${ }^{66}$ Guigonis de Caulhiaco, Inventarium sive chirurgia magna, ed. Michael R McVaugh, 2 vols, Leiden, Brill, 1997, vol. 1, p. 341.

${ }^{67}$ Ibid., p. 343; Chauliac recommends chewing fennel seed rather than fennel leaves to produce the vapour.

${ }^{68}$ Ibid., p. 344; he talks about turning the needle as it is inserted and withdrawn, and specifies avoidance of the venulas - presumably the bleeders right behind the iris?

69 "Tunc ad extollendum artem tuam, obumbrato oculo cum capucio suo, ostende sibi signum solum semel, et dicas, quid est?" (ibid.).

70 "Non secures te in opere catharactarum, quia medicine in eis parum proficiunt et operacio cum acu satis est deludosa" (ibid., p. 340).

${ }^{71}$ Nicaise publishes a document of May 1344 which identifies Guy as "magister Guigo de
}

Cauliaco, phisicus"; another of August 1359 calls him, more generally, "medicus domini nostri pape" (E Nicaise, La grande chirurgie de Guy de Chauliac, Paris, Alcan, 1890, pp. clxxi-clxxii). Guy was in major orders and so in theory forbidden to practice surgery, at least to cut or to cauterize, but the career of Theodoric Borgognoni shows (above, note 7) that papal dispensations from this prohibition were perfectly possible.

${ }^{72}$ Significantly, Guy tended to act similarly when treating cancer, preferring dietetics to surgical excision "propter scandala que vidi" (Inventarium [above, note 66], vol. 1, p. 98); Luke Demaitre, 'Medieval notions of cancer: malignancy and metaphor', Bull. Hist. Med., 1998, 72: 609-37, at p. 631 . 